\title{
Dissolved organic matter assimilation by heterotrophic bacterial groups in the western Arctic Ocean
}

\author{
Hila Elifantz ${ }^{1,2}$, Ana I. Dittel ${ }^{1}$, Matthew T. Cottrell ${ }^{1}$, David L. Kirchman ${ }^{1, *}$ \\ ${ }^{1}$ College of Marine and Earth Studies, University of Delaware, Lewes, Delaware 19958, USA \\ ${ }^{2}$ Present address: Department of Microbiology, Morrill Science Center IV North, University of Massachusetts, \\ 639 North Pleasant Street, Amherst, Massachusetts 01003-9298, USA
}

\begin{abstract}
Abundance of the major bacterial groups and dissolved organic matter (DOM) assimilation in the western Arctic Ocean were determined using fluorescence in situ hybridization (FISH) and microautoradiography combined with FISH (Micro-FISH). Cytophaga-like bacteria (25 to $65 \%$ ) and Alphaproteobacteria (17 to $40 \%$ ) were the dominant bacterial groups, followed by Gammaproteobacteria (10 to $30 \%$ ). In contrast, Betaproteobacteria and Actinobacteria were never abundant. While the distribution of Alphaproteobacteria was relatively uniform along a transect from the shelf to the basin, Cytophaga-like bacteria were more abundant on the shelf and shelf-break. Similarly, the contribution to DOM assimilation by Cytophaga-like bacteria was highest on the shelf and lowest in the basin. In contrast, Alphaproteobacteria contributed the most to DOM assimilation at the slope. About 80 to $99 \%$ of the variation in DOM assimilation was explained by bacterial group abundance. As a whole, the prokaryotic community was most active in assimilating free amino acids (50 to $60 \%$ ), followed by diatom-derived extracellular polymers (30 to $40 \%$ ) and protein (20 to $30 \%$ ). In contrast, relatively few cells assimilated glucose (10 to $20 \%)$. This study revealed substantial variation in the abundance of major bacterial groups among the Arctic regions and in the assimilation of DOM components by these bacteria.
\end{abstract}

KEY WORDS: DOM assimilation · Arctic Ocean · Micro-FISH · Heterotrophic bacteria

\section{INTRODUCTION}

Over the last 2 decades we have begun to understand the community structure and activity of heterotrophic bacteria in polar oceans and seas. Originally, it was thought that the activity of heterotrophic bacteria in these environments is low because of the cold temperature (Pomeroy \& Deibel 1986, Pomeroy et al. 1991). But more recent evidence suggests that bacterial activity is not necessarily limited by the low temperature of polar environments (Rivkin et al. 1996, Kirchman et al. 2005a). Previous studies used bulk measurements of leucine and thymidine incorporation by the total microbial community. However, it remains uncertain which fractions of the bacterial community are responsible for the measured activity. Further insights are likely to be gained from single-cell studies combined with molecular techniques to determine dissolved organic matter (DOM) assimilation by specific bacterial groups in polar systems.

The few studies of single-cell activity in the Arctic Ocean and Antarctic seas provide some clues to the function of bacteria in these waters. In the Weddell Sea, Antarctica, 13 and $49 \%$ of all prokaryotes assimilate leucine in surface and deep water, respectively, as determined by microautoradiography (Grossman 1994). These fractions are surprisingly high compared with analogous estimates (30\%) in warmer, low-latitude oceans (Smith \& del Giorgio 2003). However, the leucine concentrations (62 to $74 \mathrm{nM}$ ) used by Grossmann (1994) greatly exceeded in situ concentrations (Rich et al. 1997, Meon \& Amon 2004), which may 
overestimate the true activity. In the western Arctic Ocean, up to 60 and $45 \%$ of bacteria and archaea, respectively, assimilated various DOM compounds (Kirchman et al. 2007). Other data suggest that up to $84 \%$ of total prokaryotes are active in reducing 5cyano-2,3-ditoyl tetrazolium chloride in the western Arctic Ocean (Yager et al. 2001, Huston \& Deming 2002). These estimates are consistent with studies showing that a high fraction of bacteria (67 to 99\%) and archaea (5 to $25 \%$ ) are detected by fluorescence in situ hybridization (FISH) in Arctic water (Wells \& Deming 2003, Garneau et al. 2006, Wells et al. 2006).

Several bacterial groups are present in cold environments such as the Arctic Ocean. These groups include Bacteroidetes and several subdivisions of the Proteobacteria (Ferrari \& Hollibaugh 1999, Bano \& Hollibaugh 2002, Bowman et al. 2003). In surface waters of the Canadian Archipelago, the Cytophaga-Flavobacterium cluster makes up 9 to $41 \%$ of total cells (Wells \& Deming 2003). In the shelf and shelf-break of the Beaufort Sea, Alphaproteobacteria dominate the bacterial community, followed by Gammaproteobacteria and Cytophaga-like bacteria (Garneau et al. 2006). These 3 phylogenetic groups are also the dominant bacterial groups in Arctic pack ice (Brinkmeyer et al. 2003). In other cold water environments, such as the North Sea and the Southern Ocean, Cytophaga-like bacteria are found to dominate the community, followed by Alphaproteobacteria (Glöckner et al. 1999, Simon et al. 1999).

The role of these bacterial groups in assimilating specific DOM compounds is unknown in polar systems but it has been examined elsewhere using a combination of microautoradiography with FISH (Micro-FISH) (Lee et al. 1999, Ouverney \& Fuhrman 1999). Using this approach, previous studies suggest that Alphaproteobacteria, more so than other phylogenetic groups, contribute to uptake of low-molecular-weight DOM (LMW DOM), such as glucose, amino acids, $N$-acetylglucosamine, and dimethylsulfoniopropionate in various marine environments (Cottrell \& Kirchman 2000, Malmstrom et al. 2004, 2005, Vila et al. 2004, Elifantz et al. 2005). In contrast, uptake of high-molecularweight DOM (HMW DOM), e.g. protein, chitin, and extracellular polymeric substances (EPS), is dominated by Cytophaga-like bacteria in the Delaware Estuary (Cottrell \& Kirchman 2000, Elifantz et al. 2005). Although patterns of DOM assimilation by specific bacterial groups are starting to emerge from various studies in temperate and warm regions, it is not clear if these patterns apply to other aquatic environments, including the Arctic Ocean.

The assimilation of various DOM compounds by bacteria and archaea in the western Arctic Ocean is described in detail elsewhere (Kirchman et al. 2007) as is total prokaryotic abundance and production (Kirchman et al. in press). In the present study, we assessed the abundance and the contribution of major bacterial groups to DOM assimilation. We examined the assimilation of amino acids, glucose, protein, and EPS because of the biogeochemical importance of these compounds in all aquatic environments, including cold ones (Kirchman et al. 2001, Krembs et al. 2002, Solomon et al. 2003). The concentrations of glucose and amino acids vary regionally in the Arctic Ocean, and both compounds have high turnover rates, but amino acid uptake has exceeded glucose uptake in the Arctic waters examined to date (Rich et al. 1997, Meon $\&$ Amon 2004). These and other data led us to hypothesize that the abundant bacterial groups would dominate DOM assimilation and that more bacterial cells would take up amino acids than other compounds in the western Arctic.

\section{MATERIALS AND METHODS}

Sample collection and uptake of ${ }^{3}$ H-DOM. Surface water was collected from various locations throughout the western Arctic Ocean as part of the Shelf-Basin Interaction (SBI) program (Grebmeier \& Harvey 2005) from 5 May to 15 June (spring) and 16 July to 26 August (summer) 2002, and 15 May to 23 June and 16 July to 26 August 2004. The expeditions were designated HLY 02-01, HLY 02-03, HLY 04-02, and HLY 0403, respectively. For FISH, water samples were fixed with paraformaldehyde (PFA, 2\% final concentration) and stored at $4{ }^{\circ} \mathrm{C}$ overnight. Samples were then filtered onto $0.2 \mu \mathrm{m}$ pore-size polycarbonate filters, which were kept at $-20^{\circ} \mathrm{C}$ until analysis. For MicroFISH experiments, all samples were taken during summer 2004 from the middle of the euphotic zone at a depth at which the light intensity was $15 \%$ of surface light, except the shelf (30\% light). These depths were $7,26,13$, and $41 \mathrm{~m}$ at the shelf, shelf-break, slope, and basin, respectively.

Water samples $(20 \mathrm{ml}$ from the shelf, $60 \mathrm{ml}$ from the other locations) were incubated with $0.5 \mathrm{nM}{ }^{3} \mathrm{H}$ glucose (20 Ci mmol ${ }^{-1}$, Perkin-Elmer), $0.5 \mathrm{nM}$ mixed ${ }^{3} \mathrm{H}$-amino acids (41 $\mathrm{Ci} \mathrm{mmol}^{-1}$, Amersham), $1.2 \mu \mathrm{M}^{3} \mathrm{H}-$ EPS (concentration in glucose equivalents), or $20 \mathrm{ng}$ $\mathrm{ml}^{-1}{ }^{3} \mathrm{H}$-protein (Bradford assay). Glucose and amino acids were incubated for $2 \mathrm{~h}$ and protein and EPS for 6 to $9 \mathrm{~h}$. ${ }^{3} \mathrm{H}$-protein and ${ }^{3} \mathrm{H}$-EPS were prepared as described previously (Cottrell \& Kirchman 2000, Elifantz et al. 2005). Incubations were done at the in situ temperature in the dark. PFA ( $2 \%$ final concentration) was added to killed controls 15 min prior to the addition of the ${ }^{3} \mathrm{H}$-compounds. At the end of the incubation, samples were fixed with PFA (2\% final concentration), 
and all samples were stored at $4^{\circ} \mathrm{C}$ overnight. Samples were then filtered onto $0.2 \mu \mathrm{m}$ pore-size polycarbonate filters, which were kept at $-20^{\circ} \mathrm{C}$ until analysis.

FISH and microautoradiography analysis. FISH analysis was done using Cy3-labeled probes: Eub338 for Eubacteria, Alf968 for Alphaproteobacteria, Bet42a and Gam42a for Betaproteobacteria and Gammaproteobacteria, respectively, CF319a for Cytophagalike bacteria (Glöckner et al. 1999), and HGC96a for Actinobacteria (Roller et al. 1994). Unlabeled competitor probes were used for Betaproteobacteria and Gammaproteobacteria (Manz et al. 1992). A negative probe was used to determine nonspecific binding (Glöckner et al. 1999). For FISH analysis, data were collected from 10 fields of view.

In order to determine the maximal fraction of prokaryotes assimilating DOM, we exposed microautoradiography samples to photographic emulsion (NTB, Kodak) for 1, 3, 6, and 12 to $15 \mathrm{~d}$. At the end of each exposure time, the slides were developed as described previously (Cottrell \& Kirchman 2003). The samples were mounted with a mixture of 4:1 Citifluor (Ted Pella) and Vectashield (Vector Labs) containing $0.5 \mathrm{ng}^{-1} \mathrm{l}^{-1}$ DAPI stain, and covered with coverslips. Slides were stored at $-20^{\circ} \mathrm{C}$ until microscopic analysis.

For Micro-FISH, samples were subjected to microautoradiography after the FISH preparation as described previously (Cottrell \& Kirchman 2003). All samples were exposed to photographic emulsion for $6 \mathrm{~d}$ as determined by the time series experiment (see 'Results'). At this time, the number of cells assimilating DOM was highest in most of the samples. This allowed us to analyze the fraction of the community assimilating the compounds and to compare assimilation percentages for the compounds. At the end of the exposure time, the slides were developed as described previously (Cottrell \& Kirchman 2003). Samples were analyzed within $2 \mathrm{~d}$ after development to minimize fading of the fluorescent probes. Total numbers of cells (DAPI-stained), cells affiliated with a specific bacterial group (Cy3-labeled), and cells that assimilated the radiolabeled compound (with silver grains) were counted using a semi-automatic microscope and image analysis as described previously (Cottrell \& Kirchman 2003). Data for Micro-FISH were collected from 20 fields of view. On average the number of DAPI-stained cells inspected in 20 fields of view were 1600 cells in the shelf, 1400 in the shelf-break, 3000 in the slope, and 2600 in the basin.

Data analysis. To obtain the percent of prokaryotic cells assimilating DOM components, the number of all DAPI-stained cells with silver grains was divided by total number of DAPI-stained cells. A similar calculation was done to determine the percent of cells in each bacterial group that assimilated DOM. The number of all probe-positive cells with silver grains was divided by the number of all probe-positive cells. Finally, to calculate the contribution of bacterial groups to DOM assimilation, the number of probe-positive cells with silver grains was divided by the number of all DAPIstained cells with silver grains. Data expressed as percentages were arcsine-transformed before statistical analysis. However, the data presented here are the original percentages. To compare DOM assimilation within a sampling site or bacterial group abundance between sites, ANOVA and post hoc analyses (Tukey's HSD) were used.

\section{RESULTS}

\section{Abundance of bacterial groups}

The abundance of total prokaryotes and specific phylogenetic groups in surface waters of the Arctic Ocean during the spring and summer of 2002 and 2004 was determined by FISH (Table 1). The sampling area was divided into 4 regions according to the bottom depth: shelf (0 to $100 \mathrm{~m})$, shelf-break (100 to $500 \mathrm{~m}$ ), slope (500 to $2500 \mathrm{~m}$ ), and basin (2500 $\mathrm{m}$ and deeper). The range of bacteria detected with the Eub338 FISH probe was 60 to $90 \%$, depending on location and season (our Table 1; see also Kirchman et al. 2007). Cytophaga-like bacteria and Alphaproteobacteria were the 2 most abundant groups, comprising 17 to $65 \%$ of all prokaryotes, depending on location and season (Table 1). Cytophaga-like bacteria were relatively more abundant (percent of total prokaryotes) at the shelf and shelf-break and least abundant in the basin (ANOVA, p < 0.05). However, Alphaproteobacteria did not differ significantly between locations (ANOVA, p > 0.05). Gammaproteobacteria comprised about 10 to $30 \%$ of all DAPI-stained cells at all locations. In contrast, the abundances of Betaproteobacteria and Actinobacteria were less than $10 \%$ of all cells. Therefore, we concentrated our further investigations on Alphaproteobacteria, Gammaproteobacteria, and Cytophaga-like bacteria.

\section{Fraction of cells assimilating DOM components}

The contribution to DOM assimilation as well as the fraction of bacteria taking up DOM in the western Arctic Ocean were assessed using Micro-FISH. Prior to the Micro-FISH analysis, microautoradiography was performed without the FISH probes in order to determine the exposure time to the photographic emulsion and to assess the overall assimilation of DOM components by the entire prokaryotic community. For most 
Table 1. Relative abundance \pm SD of bacteria (Eub338-positive cells) and major groups in the western Arctic Ocean, expressed as percentage of total prokaryotes. Because abundance of Betaproteobacteria and Actinobacteria was low in 2002, these groups were not analyzed in 2004. Average of cells detected with negative control probe was $1.19 \pm 1.3 \%$. N: number of samples; -: data not available. Where $\mathrm{N}=1$, SD was calculated based on the variation between 10 fields of view; where $\mathrm{N}>1$, SD was calculated based on the number of samples

\begin{tabular}{|c|c|c|c|c|c|c|c|}
\hline \multirow[t]{2}{*}{ Location } & \multirow[t]{2}{*}{ Bacteria } & \multicolumn{3}{|c|}{ - Proteobacteria } & \multirow{2}{*}{$\begin{array}{c}\text { Cytophaga-like } \\
\text { bacteria }\end{array}$} & \multirow[t]{2}{*}{ Actinobacteria } & \multirow[t]{2}{*}{$\mathrm{N}$} \\
\hline & & Alpha- & Beta- & Gamma- & & & \\
\hline \multicolumn{8}{|l|}{ Spring 2002} \\
\hline Shelf & $73 \pm 10$ & $36 \pm 18$ & $6.5 \pm 4$ & $15 \pm 3.5$ & $31 \pm 13$ & $2 \pm 2$ & 5 \\
\hline Shelf-break & $90 \pm 3.5$ & $17 \pm 7$ & $4 \pm 2$ & $19 \pm 5$ & $42 \pm 5$ & $0.5 \pm 0.7$ & 1 \\
\hline Slope & $90 \pm 3$ & $36 \pm 8$ & $4 \pm 1.5$ & $18 \pm 4$ & $36 \pm 8$ & $1.3 \pm 1.3$ & 2 \\
\hline Basin & $86 \pm 3.5$ & $36 \pm 12$ & $3.3 \pm 1.1$ & $19 \pm 9$ & $28 \pm 6$ & $1.4 \pm 0.3$ & 3 \\
\hline \multicolumn{8}{|l|}{ Summer 2002} \\
\hline Shelf & $87 \pm 6$ & $18 \pm 10$ & $4 \pm 3$ & $11 \pm 4$ & $40 \pm 26$ & $5 \pm 5$ & 5 \\
\hline Shelf-break & $88 \pm 2$ & $26 \pm 3$ & $3 \pm 2$ & $12 \pm 7$ & $35 \pm 2$ & $3 \pm 0.5$ & 2 \\
\hline Slope & $95 \pm 3$ & $41 \pm 7.5$ & $2.4 \pm 2.5$ & $31 \pm 15$ & $51 \pm 7$ & $2.6 \pm 1$ & 1 \\
\hline Basin & $78 \pm 20$ & $32 \pm 16$ & $3 \pm 1$ & $10 \pm 3$ & $18 \pm 10$ & $4 \pm 2$ & 3 \\
\hline \multicolumn{8}{|l|}{ Spring 2004} \\
\hline Shelf & $87 \pm 1.5$ & $26 \pm 4$ & - & $21 \pm 6.5$ & $65 \pm 13$ & - & 2 \\
\hline Shelf-break & $77 \pm 6$ & $31 \pm 0$ & - & $24 \pm 6$ & $41 \pm 6.5$ & - & 2 \\
\hline Slope & $79 \pm 12$ & $30 \pm 9$ & - & $13 \pm 4$ & $32 \pm 8$ & - & 3 \\
\hline Basin & - & - & - & - & - & - & - \\
\hline \multicolumn{8}{|l|}{ Summer 2004} \\
\hline Shelf & $80 \pm 7$ & $41 \pm 1$ & - & $12 \pm 3$ & $43 \pm 9$ & - & 1 \\
\hline Shelf-break & $79 \pm 12$ & $27 \pm 7$ & - & $16 \pm 3$ & $55 \pm 15$ & - & 2 \\
\hline Slope & $80 \pm 5$ & $29 \pm 9$ & - & $18 \pm 5$ & $50 \pm 14$ & - & 1 \\
\hline Basin & $71 \pm 12$ & $43 \pm 4$ & - & $11 \pm 4$ & $26 \pm 19$ & - & 3 \\
\hline
\end{tabular}

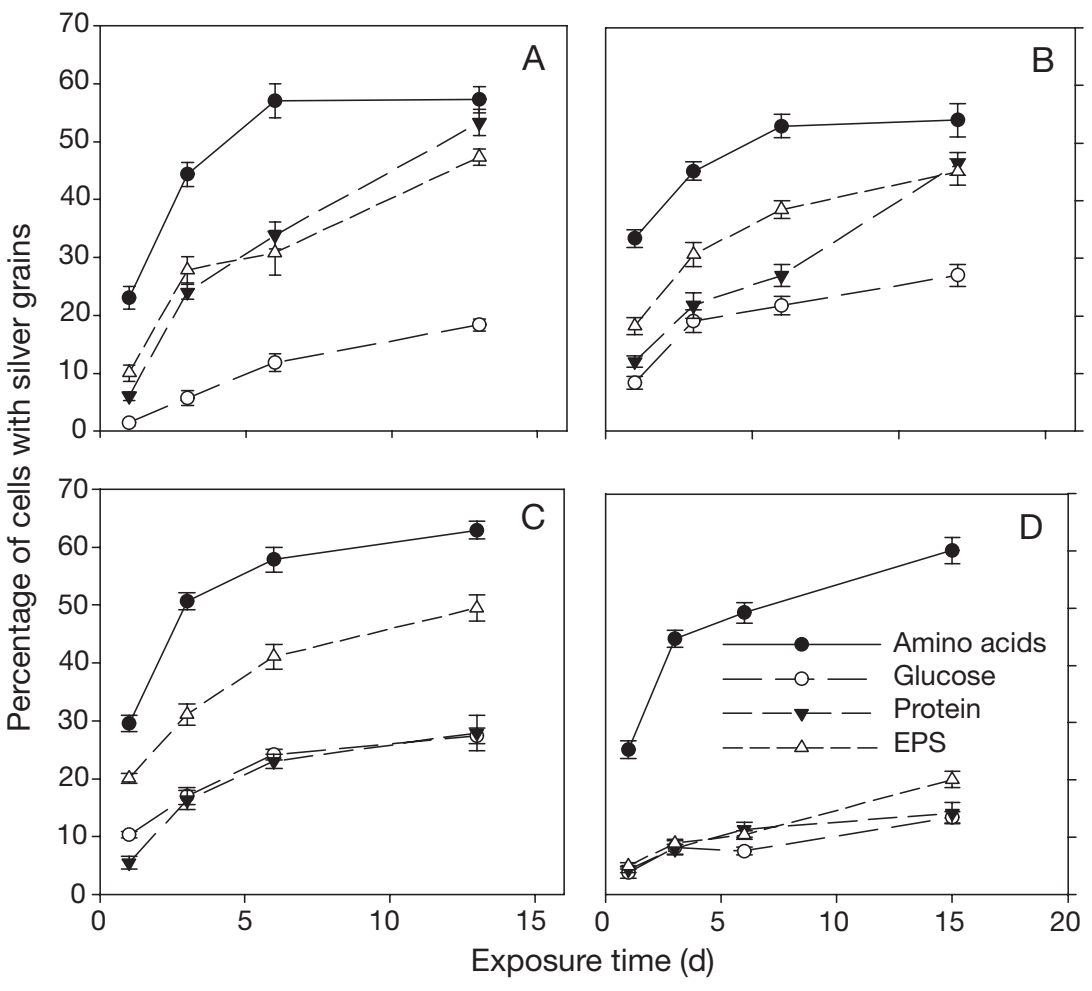

Fig. 1. Percentage of total prokaryotes active in assimilating indicated compounds as a function of exposure time to the photographic emulsion, at the (A) shelf, (B) shelf-break, (C) slope, and (D) basin. Less than $5 \%$ of cells had silver grains in killed controls. Error bars represent SE among fields samples, the highest number of active cells (cells with silver grains) was detected after 6 d (Fig. 1). Following $6 \mathrm{~d}$ there was either a slight or no increase in cells with silver grains. In some samples, the killed controls that were exposed longer than $6 \mathrm{~d}$ had over $5 \%$ of DAPI-stained cells with silver grains. In order to ensure that the background was lower than $5 \%$, the exposure time was set at $6 \mathrm{~d}$ for all micro-FISH preparations.

More cells assimilated amino acids than other compounds at all locations (Fig. 1). Over $50 \%$ of all prokaryotes assimilated amino acids. The percent of cells assimilating other DOM components varied among the different locations. At the shelf, similar fractions of prokaryotes $(\sim 30 \%)$ assimilated both protein and EPS (Fig. 1A). In contrast, more cells assimilated EPS $(\sim 40 \%)$ than protein (20 to $25 \%)$ in the shelf-break (Fig. 1B) and the slope (Fig. 1C) after $6 \mathrm{~d}$ of exposure to the photographic emulsion. The percentage of cells assimilating glucose was the lowest at all locations, only 10 to 
$20 \%$, with the exception of the slope. At that location, the percentages of cells assimilating glucose and protein were the same. The fraction of cells active in DOM assimilation was lowest in the basin (Fig. 1D).

\section{Fraction of phylogenetic groups assimilating DOM components}

The relative number of cells within the phylogenetic groups assimilating DOM components varied, but the trends were similar to those for all prokaryotes (Fig. 2). More cells in all bacterial groups assimilated amino acids (50 to $70 \%$ ) than the other compounds at all locations, with the exception of Cytophaga-like bacteria at 2 locations (Fig. 2A). Similar fractions of cells in this group assimilated amino acids and EPS (50\%) in the slope (ANOVA, Tukey's HSD, p > 0.05). In the basin, $20 \%$ of Cytophaga-like bacteria assimilated amino acids and protein (Fig. 2A). In both shelf and shelfbreak waters, similar fractions (35\%) of the cells affiliated with this group assimilated EPS and protein. Glucose was assimilated by the fewest Cytophaga-like bacterial cells at all locations, except the basin where the fractions of cells assimilating glucose and EPS were equally low (about $10 \%$ ) (Fig. 2A).

In contrast to Cytophaga-like bacteria, the fraction of Alphaproteobacteria (60 to $70 \%$ ) assimilating amino acids was the highest at all locations (Fig. 2B). Fewer cells in this group assimilated EPS in all locations (35\%) except the basin. In the basin, the fractions of Alphaproteobacteria assimilating protein, EPS, and glucose were similar (about 15\%). Also, the fractions of Alphaproteobacteria assimilating EPS and glucose in the shelf, and EPS and protein in the shelf-break were not significantly different (ANOVA, Tukey's HSD, p > 0.05). Only in the slope were the proportions of active cells in this group different for the various DOM components (ANOVA, Tukey's HSD, $\mathrm{p}<0.05$ ). In contrast to Alphaproteobacteria, the fractions of Gammaproteobacteria assimilating DOM components were significantly different from each other only in the shelf (ANOVA, Tukey's HSD, p < 0.05) (Fig. 2C). Similar to Alphaproteobacteria, EPS was the second most important compound for Gammaproteobacteria at all locations except the basin.

\section{Contribution of phylogenetic groups to DOM assimilation}

To examine the importance of a bacterial group to DOM uptake, we estimated the contribution of each phylogenetic group to the assimilation of the various DOM components as well as to the average DOM assimilation. For each compound and bacterial group, the number of DAPI-positive cells that were both probe-positive and silver grain-positive (i.e. assimilated the radioactive compounds) was divided by the number of all DAPI-positive cells that were also silver grain-positive. Either the percent of cells with silver

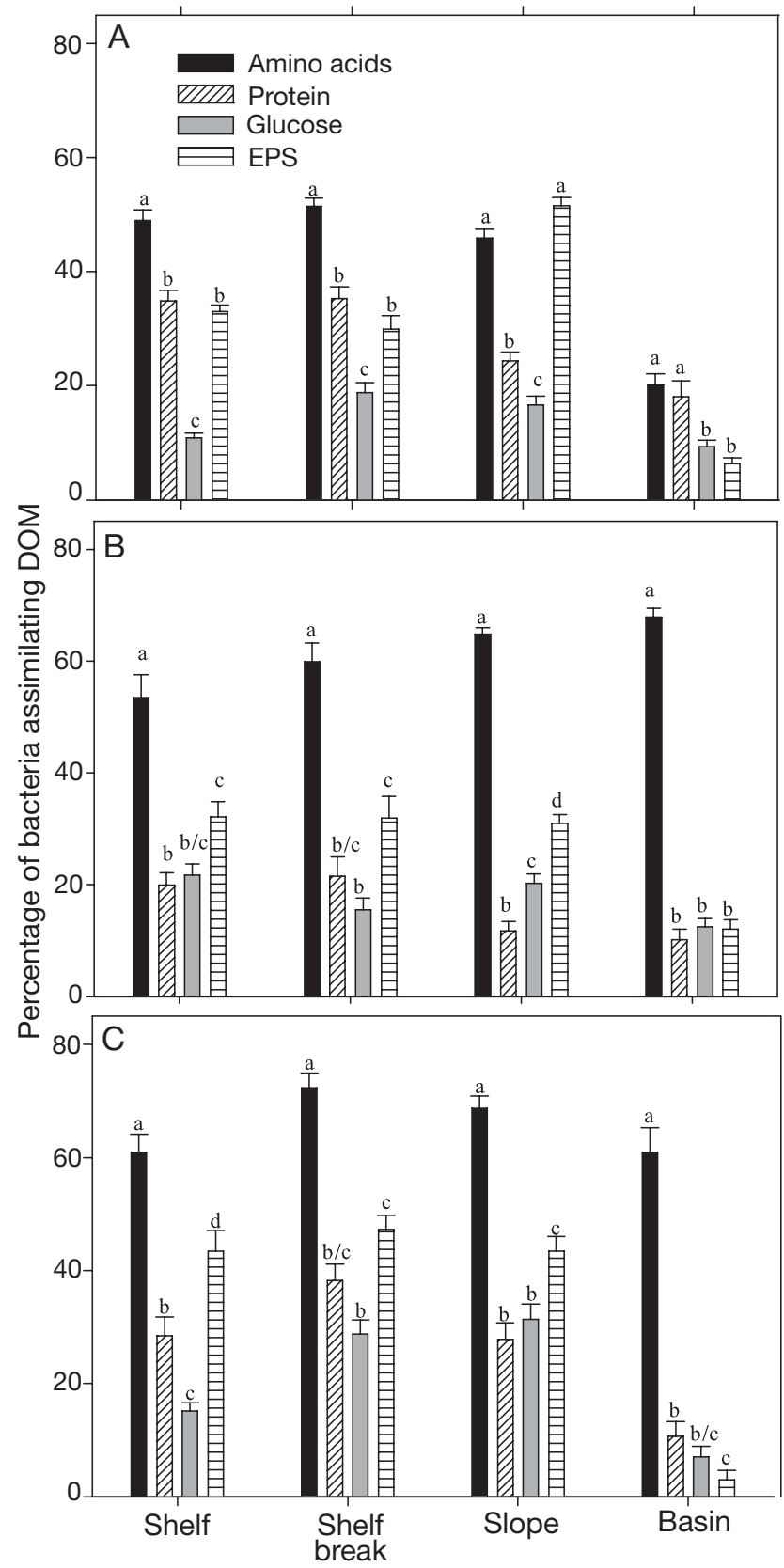

Fig. 2. Percentage of bacteria in the groups (A) Cytophagalike bacteria, (B) Alphaproteobacteria, and (C) Gammaproteobacteria that assimilated DOM compounds in summer 2004. ANOVA and Tukey's HSD tests were performed for each group within each station. Samples within each station with different letters were significantly different $(p<0.05)$. Error bars represent SE among fields 
grains or the silver grains area can be used to estimate the contribution to assimilation by a bacterial group. There was no difference in the estimates by these 2 approaches and the 2 measurements led to the same conclusions (data not shown; see also Malmstrom et al. 2004, Elifantz et al. 2005). Here we used the percent of cells with silver grains.

The average contribution of Cytophaga-like bacteria to DOM assimilation decreased from about $75 \%$ at the shelf to $25 \%$ at the basin (Fig. 3A) and followed a similar decrease in abundance of this group along the transect (Fig. 3B). Gammaproteobacteria followed the same trend (Fig. 3A), although the abundance of Gammaproteobacteria was not significantly different between shelf and basin (ANOVA, Tukey's HSD, p > 0.05) (Fig. 3B). In contrast, Alphaproteobacteria did not vary consistently along the transect in assimilation or abundance (Fig. 3). Alphaproteobacteria dominated DOM assimilation at the slope and basin, while Cytophaga-like bacteria dominated at the shelf and shelf-break. Gammaproteobacteria was the second
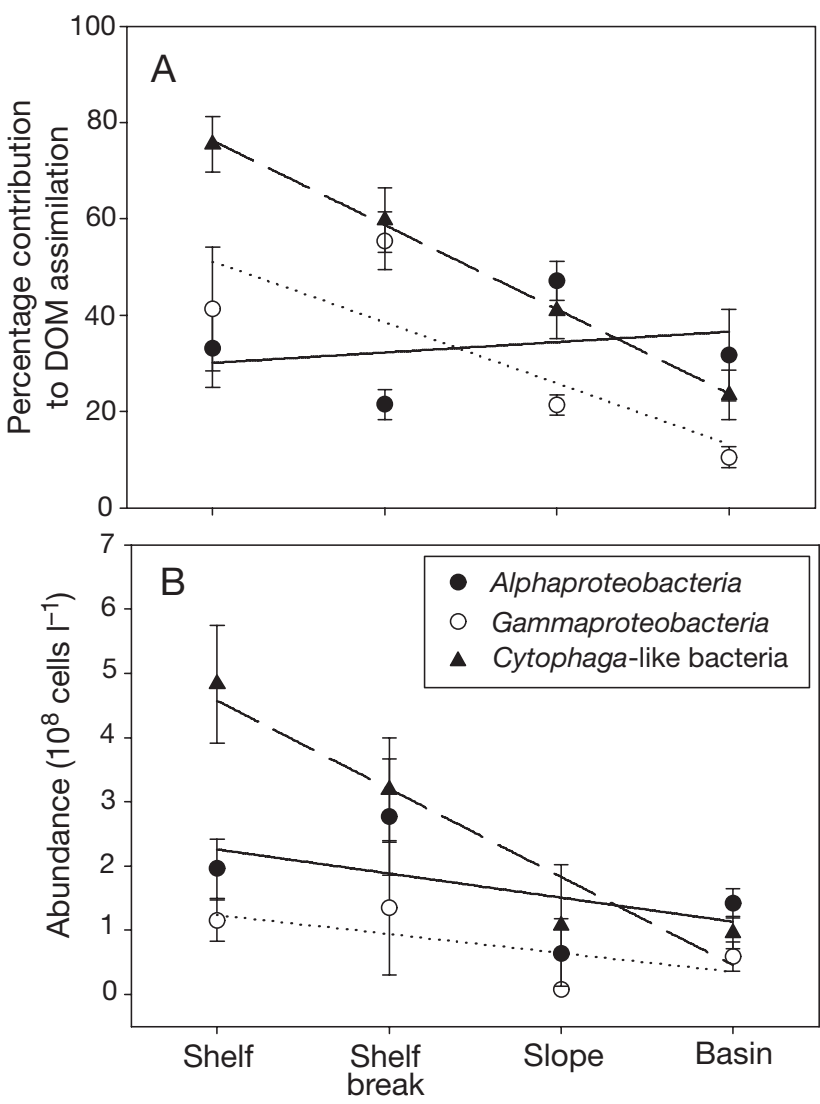

Fig. 3. (A) Average contribution to DOM assimilation by bacterial groups in summer 2004. Averages were calculated for the 4 DOM compounds (see Fig. 4) examined. Error bars represent SE. (B) Total number of cells in bacterial groups in summer 2004. Error bars represent SE among fields. Lines in both panels represent best fit of the linear regression per group most important group in DOM assimilation at the shelf and shelf-break, but assimilated the least in the slope and basin waters (Fig. 3A). The combined contribution to DOM assimilation by all bacterial groups either exceeded $100 \%$ (shelf, shelf-break, and slope) or was below $100 \%$ (basin).

The contribution of these groups to the uptake of specific DOM components varied as well (Fig. 4). Overall, Cytophaga-like bacteria contributed significantly more to protein assimilation than to amino acids (ANOVA, Tukey's HSD, p < 0.05) (Fig. 4A). In the basin, the assimilation of amino acids by Cytophagalike bacteria was also low (10\%), but assimilation of the other compounds was equal (about 30\%). In contrast, Alphaproteobacteria contributed significantly more to the uptake of glucose at the shelf and basin (ANOVA, Tukey's HSD, p < 0.05) (Fig. 4B). Also, this group contributed significantly more to the uptake of amino acid than of protein at the shelf-break and basin (ANOVA, Tukey's HSD, p < 0.05). Gammaproteobacteria contributed to the assimilation of all compounds similarly in the slope and basin. This group contributed significantly more to the assimilation of glucose (shelf and shelf-break) and EPS (shelf-break) (ANOVA, Tukey's HSD, p < 0.05) (Fig. 4C).

\section{Relationships between abundance and DOM assimilation}

To explain the observed trends, we examined how the contribution of each group was related to its abundance (Fig. 5). Overall, the correlation between relative abundance and assimilation by bacterial groups was high ( $r=0.93$ to 0.99 ). However, the correlation between abundance and assimilation was lower for assimilation of glucose by Alphaproteobacteria ( $\mathrm{r}=$ $0.36 ; \mathrm{p}<0.05)$ and of protein by Gammaproteobacteria $(\mathrm{r}=0.78 ; \mathrm{p}<0.05)$. The contribution to HMW and LMW DOM assimilation by a specific bacterial group was more apparent in this analysis. Cytophaga-like bacteria contributed more to the assimilation of HMW DOM (protein and EPS) (Fig. 5A), while Alphaproteobacteria contributed more to LMW DOM (amino acids and glucose) (Fig. 5B). As noted before, Gammaproteobacteria contributed to the assimilation of both DOM size classes similarly (Fig. 5C).

\section{DISCUSSION}

The aim of this study was to explore the contribution of specific bacterial groups to DOM assimilation by the prokaryotic community in the Arctic Ocean. We found that the bacterial community in the western Arctic 


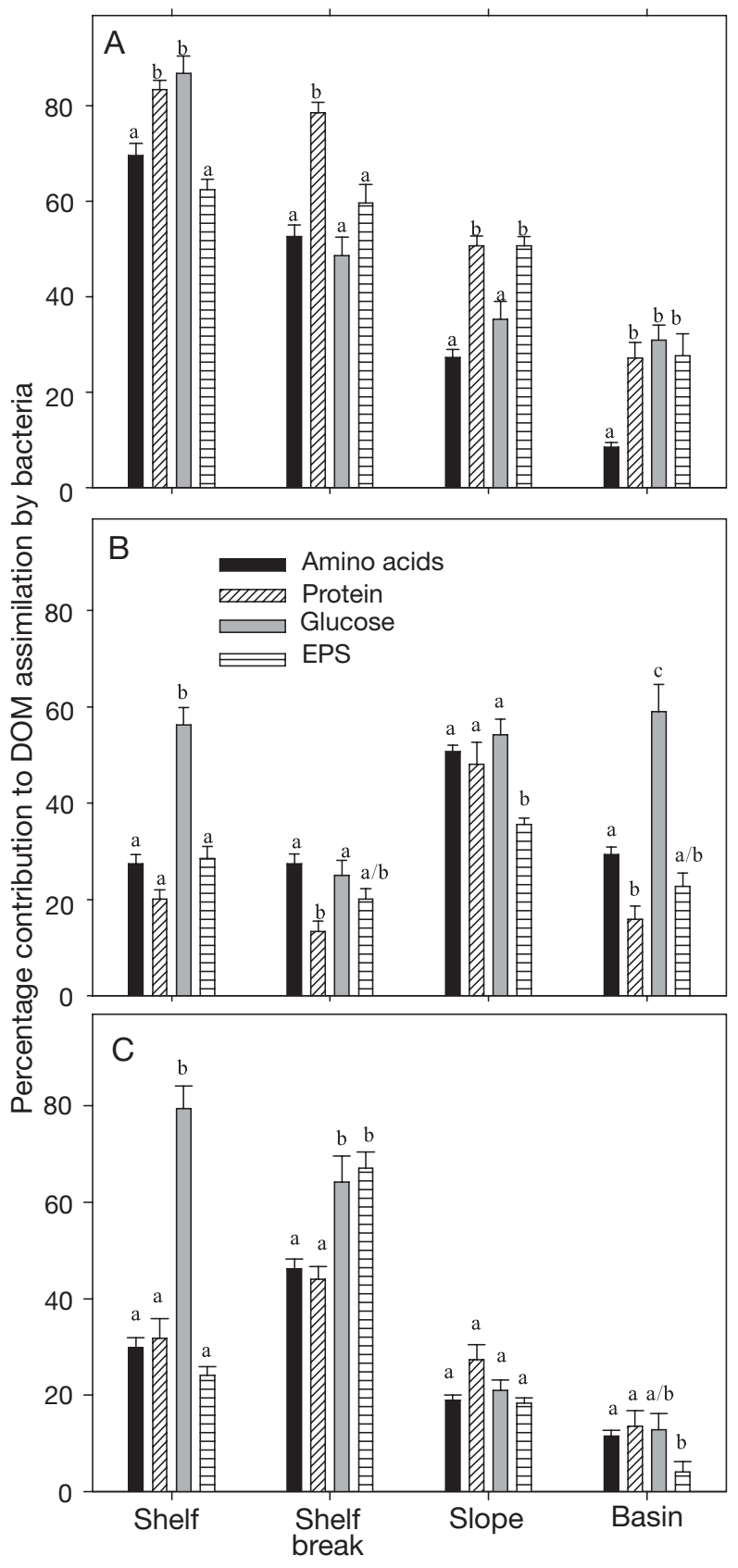

Fig. 4. Contribution to DOM assimilation by (A) Cytophagalike bacteria, (B) Alphaproteobacteria, and (C) Gammaproteobacteria, in summer 2004. ANOVA and Tukey's HSD tests were performed for each group within each station. Samples within each station with different letters are significantly different $(p<0.05)$. Error bars represent SE among fields

Ocean was highly active in the assimilation of various DOM components. The high fraction of prokaryotes assimilating amino acids ( 55\%) was surprising considering that only $30 \%$ of the total prokaryotic community assimilate amino acids in low-latitude oceans according to microautoradiography studies averaged
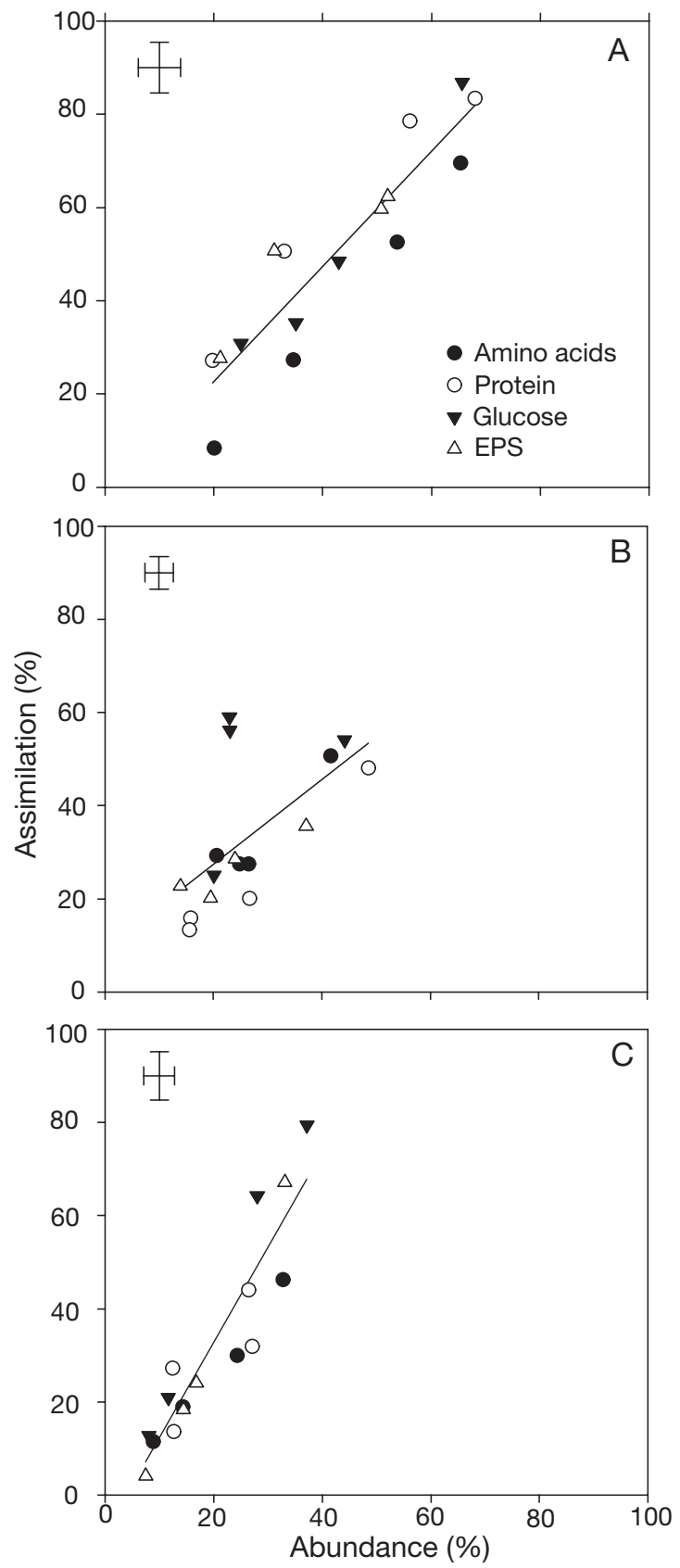

Fig. 5. Contribution to DOM assimilation as a function of abundance of (A) Cytophaga-like bacteria, (B) Alphaproteobacteria, and (C) Gammaproteobacteria. Error bars in the upper left-hand corner of each panel represent averaged error bars of all data points. Lines represent best fit of the linear regression

over all marine systems (Smith \& del Giorgio 2003). In contrast, glucose was assimilated by a lower fraction of cells in the Arctic waters we examined (10 to $20 \%$ ). The low percent of cells assimilating glucose could be attributed to rapid respiration, rather than incorporation into biomass, but our results are consistent with 
previous studies in the Arctic Ocean showing that uptake of amino acids is higher than glucose uptake (Rich et al. 1997, Meon \& Amon 2004).

Similar to our results, more prokaryotic cells assimilate amino acids than glucose and protein in the northwest Atlantic Ocean (Malmstrom et al. 2005). A possible explanation is that prokaryotes use amino acids for both nitrogen and carbon, while glucose can provide only carbon. Although protein can also supply nitrogen and carbon, the relative number of cells using it was less than for amino acids. Microautoradiography may not detect slow protein degradation and assimilation of the by-products during the relatively short incubations we used. Nevertheless, in other environments, protein is often less important than amino acids in supporting heterotrophic production (Keil \& Kirchman 1999, Rosenstock et al. 2005), and the Arctic environment may not be different in this aspect. More cells affiliated with 1 bacterial group in particular, the Alphaproteobacteria, assimilated amino acids compared to other compounds in the Arctic (the present study) and in the northwest Atlantic (Malmstrom et al. 2005). In contrast to the Arctic, in which a similar percentage of Alphaproteobacteria assimilated protein and glucose, more cells in the alphaproteobacterial group SAR11 assimilated glucose than protein in the northwest Atlantic (Malmstrom et al. 2005).

The assimilation of glucose and EPS by specific bacterial groups has been studied only in the eutrophic environment of the Delaware Estuary (Elifantz et al. 2005) and in the Arctic (the present study). The differences and similarities between these 2 environments may reveal insights into general principles governing the structuring of bacterial communities. In the Arctic Ocean, for all bacterial groups, a higher fraction of cells assimilated EPS (35 to 50\%) than glucose (10 to $30 \%$ ), with the exception of the basin. In contrast, most of the bacterial groups in the Delaware were more active in assimilating glucose than EPS (Elifantz et al. 2005). Also, the range of the fraction of cells assimilating both compounds was similar, about 5 to $40 \%$ of cells in each group. These differences between the Delaware Estuary and the western Arctic Ocean could be due to the same bacteria responding to different environmental factors or, more likely, differences in bacterial community structure between the 2 systems, in addition to the obvious differences in environmental parameters. Although the same broad bacterial groups exist in both locations, they are composed of different subgroups that probably function differently in the 2 environments (Bano \& Hollibaugh 2002, Cottrell et al. 2005, Pommier et al. 2005).

There are 2 potential problems with our estimates of the contribution of a bacterial group to DOM assimilation. First, we estimated this contribution from the percent of DOM-active bacteria (all cells with silver grains) that belonged to a bacterial group (FISH probepositive cells with silver grains), even though per-cell DOM assimilation by active bacteria can vary greatly (Cottrell \& Kirchman 2003). However, the distribution of per-cell assimilation is similar among the broad groups we examined (Cottrell \& Kirchman 2003), and there is a high correlation between percent of DOMactive bacteria belonging to a group and the percent of total silver grain area attributable to that group (Cottrell \& Kirchman 2003, Elifantz et al. 2005, the present study). There is also a high correlation between silver grain area and bulk leucine incorporation rates (Sintes \& Herndl 2006).

The second problem is that the sum of contribution to DOM assimilation by the 3 bacterial groups did not equal $100 \%$. In the shelf and shelf-break the sum of the averaged contribution to DOM assimilation was significantly greater than $100 \%$ (Student's $t$-test, 1sided $\mathrm{p}<0.05)$, but in the slope and basin it was not. This difference from $100 \%$ is probably because our estimates of the standard error were too low. If the standard errors were larger, the difference from $100 \%$ would not have been significant. Most of the variation $(>80 \%)$ in microscopic counts is among microscopic fields (the source of our error estimates), but other levels of replication sometimes can contribute substantially (Kirchman et al. 1982). Another explanation is that the probes bind nonspecifically. In contrast in the basin, the total contribution by all groups (including Archaea) we examined was less than $100 \%$, perhaps because other groups not examined here were responsible for some of the DOM assimilation. Also, the FISH probes we used may not detect all members of the groups we examined.

While the fractions of cells affiliated with a bacterial group assimilating DOM were similar (Fig. 2), the contribution to DOM uptake differed among the groups (Fig. 4), mainly because of differences in the abundance of these bacterial groups. Abundance explained 80 to $99 \%$ of the assimilation of all compounds by bacterial groups in these Arctic waters. In contrast, only 35 to $55 \%$ of bacterial production (Cottrell \& Kirchman 2003) and assimilation of glucose and EPS (Elifantz et al. 2005) in the Delaware Estuary could be explained by abundance. The differences between the Delaware Estuary and the Arctic Ocean imply that the bacterial communities in the 2 environments are controlled by different combinations of 'top-down' factors such as grazing and viral lysis, and 'bottom-up' factors such as DOM availability.

The abundance of Cytophaga-like bacteria declined from the shelf to the basin. The contribution of this group to DOM assimilation had a similar trend, with the highest contribution in shelf waters. This pattern 
may be due to the distribution of particles and the affinity of Cytophaga-like bacteria to particles and associated labile organic matter either in particles or DOM. Cytophaga-like bacteria are abundant on particles in estuaries and other marine environments (DeLong et al. 1993, Crump et al. 1999) and appear to favor HMW DOM in the Arctic (the present study) and elsewhere (Cottrell \& Kirchman 2000, Elifantz et al. 2005). Concentration of particulate organic carbon decreases from the shelf to the basin (Bates et al. 2005), as did the abundance of Cytophaga-like bacteria (the present study), although there was no correlation between Cytophaga-like bacteria and particles in the Beaufort Sea (Garneau et al. 2006). The high concentration of particles and the flux of labile DOM may affect the abundance and activity of Cytophaga-like bacteria (Alonso \& Pernthaler 2006). Similarly, the contribution of Gammaproteobacteria to DOM assimilation decreased from shelf to basin. In coastal waters off the Columbia River, Gammaproteobacteria were also abundant on particles (Crump et al. 1999), suggesting that, analogous to Cytophaga-like bacteria, the contribution to DOM assimilation by Gammaproteobacteria may also be related to particle abundance and DOM. Both Gammaproteobacteria and Cytophaga-like bacteria may be selected for by high concentrations or supply rates of labile DOM and particulate organic matter in the Arctic environment.

In contrast to Cytophaga-like bacteria and Gammaproteobacteria, Alphaproteobacteria appeared to account for more DOM assimilation at the slope and basin. Also, it contributed more to the assimilation of LMW than HMW DOM, similar to what was found in the Delaware Estuary and the North Atlantic Ocean (Cottrell \& Kirchman 2000, Elifantz et al. 2005, Malmstrom et al. 2005). Labile LMW DOM is usually found in lower concentrations than HMW DOM in marine environments (Benner et al. 1992), and concentrations may be as important as molecular size in determining the activity of Alphaproteobacteria. This group may have special adaptations which allow them to use compounds in low concentrations and may explain why Alphaproteobacteria, and in particular the SAR11 clade, are abundant in open oceans, including the Arctic (Bano \& Hollibaugh 2002, Morris et al. 2002, Malmstrom et al. 2007). Of course, the 3 phylogenetic groups studied here are composed of a broad array of subgroups that may contribute differently to the assimilation of various DOM compounds (Malmstrom et al. 2007). For this reason, it is remarkable that the broad groups differ at all and that there are any consistent patterns among environments at this phylogenetic level.

Few studies have examined the abundance of bacterial groups in polar and subpolar waters. The abun- dance of Alphaproteobacteria in the western Arctic (17 to $40 \%$ ) was similar to that reported in the North Sea (Eilers et al. 2000), but it is higher than in Antarctic waters and the Southern Ocean (4 to $11 \%$; Glöckner et al. 1999, Simon et al. 1999). Gammaproteobacteria were also less abundant in the North Sea and the Southern Ocean than in the Arctic waters we examined (10 to $30 \%$ ). The abundances of all proteobacterial groups in the present study were comparable to the abundances found in the Beaufort Sea (Garneau et al. 2006), but Cytophaga-like bacteria were less numerous in the Beaufort Sea than in the present study. Although the western Arctic is affected by rivers (Macdonald et al. 2002), the bacterial community composition does not seem to be influenced by them. In the present study, the abundance of Betaproteobacteria and Actinobacteria, which are abundant in rivers and other freshwater environments (Kirchman et al. 2005b), was much lower than the other bacterial groups examined. Also, betaproteobacterial abundance declined from the Mackenzie River to the shelf, whereas the abundance of other bacterial groups such as Alphaproteobacteria increased (Garneau et al. 2006). This suggests that if any freshwater groups are transported into the Arctic basins from rivers, they do not survive for long.

\section{CONCLUSIONS}

The prokaryotic community in the Arctic Ocean was highly active in DOM assimilation, especially of amino acids. Most of this assimilation was explained by bacterial group abundance, unlike analogous studies in low-latitude waters, suggesting differences in how the composition of these bacterial communities is regulated. However, even though the Arctic is fundamentally different from temperate regions, the general pattern of the DOM assimilation by bacterial groups is similar, suggesting that bacteria within a group share similar functions regardless of location. These data may explain the cosmopolitan distribution of major bacterial groups. Further investigations in both coldand warm-water environments as well as subpopulations of the major bacterial groups are needed to further test these hypotheses and to increase our knowledge of DOM processing by specific prokaryotic groups.

Acknowledgements. We thank R. R. Malmstrom, K. Preen, A. Parker, and our SBI colleagues for help collecting samples. We also thank B. C. Crump for his valuable comments on an earlier draft that improved this manuscript. This work was supported by NSF grant OPP 0124733 and by DOE (DF-FG0297 ER 62479). A Fulbright Graduate Fellowship provided support for H.E. 


\section{LITERATURE CITED}

Alonso C, Pernthaler J (2006) Roseobacter and SAR11 dominate microbial glucose uptake in coastal North Sea waters. Environ Microbiol 8:2022-2030

Bano N, Hollibaugh JT (2002) Phylogenetic composition of bacterioplankton assemblages from the Arctic Ocean. Appl Environ Microbiol 68:505-518

Bates NR, Hansell DA, Moran SB, Codispoti LA (2005) Seasonal and spatial distribution of particulate organic matter (POM) in the Chukchi and Beaufort Seas. Deep-Sea Res II 52:3324-3343

Benner R, Pakulski JD, McCarthy M, Hedges JI, Hatcher PG (1992) Bulk chemical characteristics of dissolved organicmatter in the ocean. Science 255:1561-1564

Bowman JP, McCammon SA, Gibson JAE, Robertson L, Nichols PD (2003) Prokaryotic metabolic activity and community structure in Antarctic continental shelf sediments. Appl Environ Microbiol 69:2448-2462

Brinkmeyer R, Knittel K, Jürgens J, Weyland H, Amann R, Helmke E (2003) Diversity and structure of bacterial communities in Arctic versus Antarctic pack ice. Appl Environ Microbiol 69:6610-6619

Cottrell MT, Kirchman DL (2000) Natural assemblages of marine proteobacteria and members of the CytophagaFlavobacter cluster consuming low- and high- molecularweight dissolved organic matter. Appl Environ Microbiol 66:1692-1697

Cottrell MT, Kirchman DL (2003) Contribution of major bacterial groups to bacterial biomass production (thymidine and leucine incorporation) in the Delaware estuary. Limnol Oceanogr 48:168-178

Cottrell MT, Waidner LA, Yu L, Kirchman DL (2005) Bacterial diversity of metagenomic and PCR libraries from the Delaware River. Environ Microbiol 7:1883-1895

Crump BC, Armbrust EV, Baross JA (1999) Phylogenetic analysis of particle-attached and free-living bacterial communities in the Columbia River, its estuary, and the adjacent coastal ocean. Appl Environ Microbiol 65:3192-3204

DeLong EF, Franks DG, Alldredge AL (1993) Phylogenetic diversity of aggregate-attached vs free-living marine bacterial assemblages. Limnol Oceanogr 38:924-934

Eilers H, Pernthaler J, Glöckner FO, Amann R (2000) Culturability and in situ abundance of pelagic bacteria from the North Sea. Appl Environ Microbiol 66:3044-3051

Elifantz H, Malmstrom RR, Cottrell MT, Kirchman DL (2005) Assimilation of polysaccharides and glucose by major bacterial groups in the Delaware Estuary. Appl Environ Microbiol 71:7799-7805

Ferrari VC, Hollibaugh JT (1999) Distribution of microbial assemblages in the Central Arctic Ocean Basin studied by PCR/DGGE: analysis of a large data set. Hydrobiologia 401:55-68

Garneau MÈ, Vincent WF, Alonso-Sáez L, Gratton Y, Lovejoy C (2006) Prokaryotic community structure and heterotrophic production in a river-influenced coastal arctic ecosystem. Aquat Microb Ecol 42:27-40

Glöckner FO, Fuchs BM, Amann R (1999) Bacterioplankton compositions of lakes and oceans: a first comparison based on fluorescence in situ hybridization. Appl Environ Microbiol 65:3721-3726

Grebmeier JM, Harvey HR (2005) The western Arctic shelfbasin interactions (SBI) project: an overview. Deep-Sea Res II 52:3109-3115

Grossman S (1994) Bacterial activity in sea ice and open water of the Weddell Sea, Antarctica: a microautoradiography study. Microb Ecol 28:1-18
Huston AL, Deming, JW (2002) Relationships between microbial extracellular enzymatic activity and suspended and sinking particulate organic matter: seasonal transformation in the North Water. Deep-Sea Res II 49:5211-5225

Keil RG, Kirchman DL (1999) Utilization of dissolved protein and amino acids in the northern Sargasso Sea. Aquat Microb Ecol 18:293-300

Kirchman DL, Sigda J, Kapuscinski R, Mitchell R (1982) Statistical analysis of the direct count method for enumerating bacteria. Appl Environ Microbiol 43:769-776

Kirchman DL, Meon B, Ducklow HW, Carlson CA, Hansell DA, Steward GF (2001) Glucose fluxes and concentrations of dissolved combined neutral sugars (polysaccharides) in the Ross Sea and Polar Front Zone, Antarctica. Deep-Sea Res II 48:4179-4197

Kirchman DL, Malmstrom RR, Cottrell MT (2005a) Control of bacterial growth by temperature and organic matter in the western Arctic. Deep-Sea Res II 52:3386-3395

Kirchman DL, Dittel AI, Malmstrom RR, Cottrell MT (2005b) Biogeography of major bacterial groups in the Delaware Estuary. Limnol Oceanogr 50:1697-1706

Kirchman DL, Elifantz H, Dittel AI, Malmstrom RR, Cottrell MT (2007) Standing stocks and activity of archaea and bacteria in the western Arctic Ocean. Limnol Oceanogr 52:495-507

Kirchman DL, Hill V, Cottrell MT, Gradinger R, Malmstrom RR, Parker AE (in press) Standing stocks, production and respiration of phytoplankton and bacteria in the western Arctic Ocean. Deep-Sea Res II

Krembs C, Eicken H, Junge K, Deming JW (2002) High concentrations of exopolymeric substances in Arctic winter sea ice; implications for the polar ocean carbon cycle and cryoprotection of diatoms. Deep-Sea Res I 49:2163-2181

Lee N, Nielsen PH, Andreasen KH, Juretschko S, Nielsen JL, Schleifer KH, Wagner M (1999) Combination of fluorescent in situ hybridization and microautoradiography - a new tool for structure-function analyses in microbial ecology. Appl Environ Microbiol 65:1289-1297

Macdonald RW, McLaughlin FA, Carmack EC (2002) Fresh water and its sources during the SHEBA drift in the Canada Basin of the Antarctic Ocean. Deep-Sea Res I 49:1769-1785

Malmstrom RR, Kiene RP, Kirchman DL (2004) Identification and enumeration of bacteria assimilating dimethylsulfoniopropionate (DMSP) in the North Atlantic and Gulf of Mexico. Limnol Oceanogr 49:597-606

Malmstrom RR, Cottrell MT, Elifantz H, Kirchman DL (2005) Biomass production and dissolved organic matter assimilation by SAR11 bacteria in the Northwest Atlantic Ocean. Appl Environ Microbiol 71:2979-2986

Malmstrom RR, Straza TRA, Cottrell MT, Kirchman DL (2007) Diversity, abundance, and biomass production of bacterial groups in the western Arctic Ocean. Aquat Microb Ecol $47: 45-55$

Manz W, Amann R, Ludwig W, Wagner M, Schleifer KH (1992) Phylogenetic oligodeoxynucleotide probes for the major subclasses of proteobacteria-problems and solutions. Syst Appl Microbiol 15:593-600

Meon B, Amon RMW (2004) Heterotrophic bacterial activity and fluxes of dissolved free amino acids and glucose in the Arctic rivers Ob, Yenisei and the adjacent Kara Sea. Aquat Microb Ecol 37:121-135

Morris RM, Rappe MS, Connon SA, Vergin KL, Siebold WA, Carlson CA, Giovannoni SJ (2002) SAR11 clade dominates ocean surface bacterioplankton communities. Nature 420: 806-810

Ouverney CC, Fuhrman JA (1999) Combined microautoradi- 
ography-16S rRNA probe technique for determination of radioisotope uptake by specific microbial cell types in situ. Appl Environ Microbiol 65:1746-1752

Pomeroy LR, Deibel D (1986) Temperature regulation of bacterial activity during the spring bloom in Newfoundland coastal waters. Science 233:359-361

Pomeroy LR, Wiebe WJ, Deibel D, Thompson RJ, Rowe GT, Pakulski JD (1991) Bacterial responses to temperature and substrate concentration during the Newfoundland spring bloom. Mar Ecol Prog Ser 75:143-159

Pommier T, Pinhassi J, Hagström Å (2005) Biogeographic analysis of ribosomal RNA clusters from marine bacterioplankton. Aquat Microb Ecol 41:79-89

Rich JH, Gosselin M, Sherr E, Sherr B, Kirchman DL (1997) High bacterial production, uptake and concentrations of dissolved organic matter in the Central Arctic Ocean. Deep-Sea Res II 44:1645-1663

Rivkin RB, Anderson MR, Lajzerowicz C (1996) Microbial processes in cold oceans. I. Relationship between temperature and bacterial growth rate. Aquat Microb Ecol 10: 243-254

Roller C, Wagner M, Amann R, Ludwig W, Schleifer KH (1994) In-situ probing of gram-positive bacteria with high DNA G+C content using 235-ribosomal-RNA-targeted oligonucleotides. Microbiology UK 140:2849-2858

Rosenstock B, Zwisler W, Simon M (2005) Bacterial consumption of humic and non-humic low and high molecular weight DOM and the effect of solar irradiation on the turnover of labile DOM in the Southern Ocean. Microb Ecol 50:90-101

Simon M, Glöckner FO, Amann R (1999) Different community structure and temperature optima of heterotrophic pico-

Editorial responsibility: Craig Carlson,

Santa Barbara, California, USA plankton in various regions of the Southern Ocean. Aquat Microb Ecol 18:275-284

Sintes E, Herndl GJ (2006) Quantifying substrate uptake by individual cells of marine bacterioplankton by catalyzed reporter deposition fluorescence in situ hybridization combined with microautoradiography. Appl Environ Microbiol 72:7022-7028

Smith EM, del Giorgio PA (2003) Low fractions of active bacteria in natural aquatic communities? Aquat Microb Ecol 31:203-208

Solomon CM, Lessard EJ, Keil RG, Foy MS (2003) Characterization of extracellular polymers of Phaeocystis globosa and $P$. antarctica. Mar Ecol Prog Ser 250:81-89

Vila M, Simó R, Kiene RP, Pinhassi J, González JA, Moran MA, Pedrós-Alió C (2004) Use of microautoradiography combined with fluorescence in situ hybridization to determine dimethylsulfoniopropionate incorporation by marine bacterioplankton taxa. Appl Environ Microbiol 70: 4648-4657

Wells LE, Deming JW (2003) Abundance of bacteria, the Cytophaga-Flavobacterium cluster and archaea in cold oligotrophic waters and nepheloid layers of the Northwest Passage, Canadian Archipelago. Aquat Microb Ecol 31: $19-31$

Wells LE, Cordray M, Bowerman S, Miller LA, Vincent WF, Deming JW (2006) Archaea in particle-rich waters of the Beaufort Shelf and Franklin Bay, Canadian Arctic: clues to an allochthonous origin? Limnol Oceanogr 51:47-59

Yager PL, Connelly TL, Mortazavi B, Wommack KE and others (2001) Dynamics bacterial and viral response to an algal bloom at subzero temperatures. Limnol Oceanogr 46:790-801

Submitted: March 19, 2007; Accepted: September 18, 2007 Proofs received from author(s): December 4, 2007 